\title{
PENGEMBANGAN E-MODUL FUNTEACH BERBASIS EDUTAINMENT MENINGKATKAN INFORMATION COMMUNICATION AND TECHNOLOGY GURU SEKOLAH DASAR
}

\author{
Nur Raisah, Risha Setyawati, Auliyah Lisyuffah Riuddani, Farah Nabila Nur Afifah, \\ Muhammad Nurwidya Ardiansyah, Fery Muhamad Firdaus \\ Fakultas Ilmu Pendidikan, Universitas Negeri Yogyakarta \\ e-mail: nurraisah.2019@student.uny.ac.id
}

\begin{abstract}
Abstrak
Pendahuluan: Kecakapan guru yang profesional pada abad 21 memiliki tantangan yang sangat kompleks guna menghadapi tantangan global. Guru dituntut untuk mampu beradaptasi dengan adanya teknologi. Pemanfaatan variasi teknologi mengharuskan guru untuk memiliki penguasaan dan pemanfaatan Information and Communication Technology (ICT), namun banyak guru yang belum memiliki kemampuan ICT yang maksimal. Tujuan: Penelitian ini bertujuan untuk menghasilkan produk e-modul sebagai pedoman bagi guru sekolah dasar untuk meningkatkan kompetensi ICT. Metode: Penelitian ini merupakan wawancara pengembangan (Research and Development). Model pengembangan yang digunakan yaitu ADDIE terdiri dari lima tahapan yang meliputi analyze, design, development, implementation, dan evaluation. Instrumen penelitian berupa kuesioner serta dilakukan kebijakan merdeka belajar wawancara. Tim penilai produk terdiri: ahli materi, ahli materi, dan respon oleh guru. Hasil: 1) Peneliti telah menghasilkan produk E-modul Funteach sebagai pedoman bagi guru untuk meningkatkan kompetensi ICT. Meliputi karakteristik proses (analisis, desain produk, pengembangan, implementasi, dan evaluasi) dan karakteristik produk (judul, petunjuk penggunaan, pendahuluan, materi fun learning, materi edutainment, fun media pembelajaran penyampaian materi, dan fun media evaluasi). 2) E- modul Funteach memperoleh penilaian dari ahli materi dengan mendapat skor rata-rata 4,95 yang berarti sangat layak dan penilaian ahli media dengan mendapat skor rata-rata 4,75 yang berarti sangat layak, 3) respon dan tanggapan guru kelas 4 dan 5 SD terhadap Emodul Funteach memperoleh skor rata-rata yang berarti 4,5 yang berarti sangat layak untuk diimplementasikan lebih lanjut. Kesimpulan: sesuai batas-batas hasil review ahli dan tanggapan guru, produk e-modul Funteach dalam penelitian ini dapat digunakan oleh guru sekolah dasar.
\end{abstract}

Kata Kunci: e-modul, edutainment, kompetensi ICT, sekolah dasar

\section{DEVELOPMENT OF EDUTAINMENT-BASED FUNTEACH E-MODULES INCREASING INFORMATION COMMUNICATION AND TECHNOLOGY OF ELEMENTARY SCHOOL TEACHERS}

\begin{abstract}
Introduction: Professional teacher skills in the 21st century have very complex challenges to face global challenges. Teachers are required to be able to adapt to technology. Utilization of variations in technology requires teachers to have mastery and use of Information and Communication Technology (ICT), but many teachers do not yet have maxsimal ICT skills. Objective: This study aims to produce an e-module product as a guide for elementary school teachers to improve ICT competence. Methods: This research is a research and development research. The development model used, namely ADDIE, consists of five stages which include analyze, design, development, implementation, and evaluation. Research instruments in the form of questionnaires and interviews. The product assessment team consists of: material experts, material experts, and teacher responses. Results: 1) Researchers have produced Funteach E-module products as a guide for teachers to improve ICT competence. Includes process characteristics (analysis, product design, development, implementation, and evaluation) and product characteristics (title, instructions for use, introduction, fun learning material, edutainment material, fun learning media delivery of material, and fun media
\end{abstract}


evaluation). 2) E-module Funteach received an assessment from material experts by getting an average score of 4.95 which means very feasible and media expert assessment by getting an average score of 4.75 which means very feasible, 3) the responses and responses of grade 4 teachers and 5 elementary schools for the Funteach E-module obtained an average score of 4.5 which means it is very feasible to be implemented further. Conclusion: according to the results of expert reviews and teacher responses, the Funteach e-module product in this study can be used by elementary school teachers.

Keywords: : e-module, edutainment, ICT competency, elementary school

\section{PENDAHULUAN}

Keterampilan profesional guru di abad 21 menghadapi tantangan yang sangat kompleks untuk menghadapi adanya tantangan terhadap global. Adanya kebijakan pembelajaran mandiri yang digagas oleh Menteri Pendidikan Nadiem Makariem memunculkan inisiatif baru untuk mewujudkan reformasi mutu pendidikan. Kebijakan merdeka belajar, menghendaki guru mempunyai "growth mindset" sehingga mampu melaksanakan variasi inovasi pembelajaran bagi peserta didik dengan efektif (Satriawan dkk., 2021). Program guru penggerak merupakan salah satu program dari merdeka belajar guna mendongkrak potensi guru dalam menunjang kemandirian peserta didik saat belajar (Nadiem, 2020).

Seiring dengan kemajuan teknologi dan komunikasi, kemampuan pemanfaatan Teknologi Informasi dan Komunikasi (TIK) bagi seorang guru merupakan potensi yang sangat krusial dalam pelaksanaan kegiatan pembelajaran. (Rivalina, 2014). Teknologi Informasi dan Komunikasi atau Information and Communication Technology (ICT) merupakan perangkat teknologi yang menyediakan bentuk atau simbol informasi berupa tulisan, suara, maupun visual (Prawiradilaga, 2013).

Kedudukan dan fungsi dari ICT bagi pembelajaran pada era digital menghendaki guru agar dapat memanfaatkan ICT dalam kegiatan belajar mengajar. Kompetensi ICT memiliki peranan yang sangat penting bagi guru dalam meningkatkan kompetensi pedagogik dan profesional (Batubara, 2017). Bersumber pada Peraturan Menteri Pendidikan Nasional Nomor 16 Tahun 2007 tentang Kompetensi ICT sebagai sarana self development dan ICT sebagai penopang pada proses di pembelajaran (Niarsa, 2013).

Kerangka UNESCO mencakup enam bagian dari dimensi kompetensi TIK, yang intinya adalah guru menguasai TIK untuk mendukung kegiatan pendidikan (UNESCO, 2011). Keenam poin tersebut dibagi menjadi tiga tingkatan, antara lain: 1) Menguasai pengetahuan dasar TIK (Technology Literacy), 2) Menggunakan TIK untuk memperdalam dan merekayasa pengetahuan (Knowledge Deepening), serta memiliki kemampuan menggunakan TIK untuk menciptakan pengetahuan (Knowledge Deepening) Pembuatan.

Kemendikbud melakukan riset terkait metode pembelajaran yang diimplementasikan pada 350 Sekolah Dasar dalam Program Kinerja dan Akuntabilitas (KIAT) guru diperoleh hasil bahwa $84 \%$ dari keseluruhan guru hanya memanfaatkan aplikasi WhatsApp, $58,80 \%$ guru memberikan soal, $17,10 \%$ tidak terjadi proses belajar mengajar dan hanya $12 \%$ yang membuat video pembelajaran (Kemendikbud, 2020). Dilain sisi, pemanfaatan variasi media pembelajaran menjadi hal yang sangat penting mengingat karakter siswa sekolah dasar yang senang bermain, suka hal menantang, dan menyukai pembelajaran yang menyenangkan.

Beberapa studi menginformasi dampak minimnya kreativitas guru dalam pemanfaatan aplikasi pembelajaran menyebabkan sekitar 69 $\%$ dari 4.000 anak merasa jenuh ketika belajar dari rumah (Ramly, 2020). Penelitian lain juga menunjukkan sekitar $72 \%$ responden merasa jenuh, 19\% sulit berkonsentrasi, 14\% merasa bingung, 13\% menanggung kesusahan tidur, $10 \%$ stress atau tertekan, dan 9\% letih dan kesepian (Save The Children, 2020). Berdasarkan hasil wawancara tim peneliti dengan guru sekolah dasar, ditemukan bahwa belum ada modul atau panduan guru berbasis hiburan dan pembelajaran untuk meningkatkan keterampilan TIK, terutama dalam menciptakan pembelajaran online yang menarik bagi siswa (17/07/2021). Akibatnya guru dapat merasa frustasi jika tidak mengerti terkait pembuatan media pembelajaran berbasis teknologi (Alifia dkk., 2020). 
Sejalan dengan kemajuan media teknologi informasi pada pendidikan, maka beragam bahan belajar juga mendapati perkembangan dengan berbagai variasi. Emodul merupakan salah satu media yang efektif, efisien, dan mengedepankan kemandirian (Fausiah, 2015). E-Modul (Modul digital) dimaksudkan sebagai bahan ajar modul untuk menyampaikan materi menggunakan perangkat digital. Bagian materi dapat dipresentasikan dengan tampilan yang memukau, menggunakan beragam media berupa gambar, teks, audio, maupun video (Nurohman, 2011). E-modul juga dapat disempurnakan dengan penambahan tes/kuis yang memungkinkan adanya feedback secara langsung (Sugihartini \& Jayanta, 2017).

Kemajuan teknologi yang semakin pesat mengharuskan guru untuk menghadapi perkembangan zaman secara lebih intensif. Guru dituntut untuk mampu beradaptasi dengan teknologi, mencoba berbagai cara agar materi pembelajaran lebih bagus, dan memastikan kegiatan pembelajaran dilaksanakan dengan baik. Hal ini dapat dicapai dengan menerapkan kemampuan TIK guru Kompetensi ICT tidak hanya untuk pengembangan potensi diri tetapi juga dapat meningkatkan kualitas pembelajaran yang diampunya (Rivalina, 2014). Penelitian terdahulu yang dilakukan oleh Kuncahyono, 2019 dalam Pengembangan Softskill Teknologi Pembelajaran Melalui Pembuatan E-modul Bagi Guru sekolah dasar menunjukkan konsep materi sudah diintegrasikan dengan multimedia yang bersifat interaktif untuk siswadas. E-modul yang dikembangkan juga menunjukkan kekurangan bahwa dalam penelitian ini materi belum terdapat multimedia berupa video atau suara guna memperjelas konsep dan mempermudah pemahaman pembaca. Penelitian lain yang dilakukan oleh Syahid, dkk (2019) terkait dengan Pengembangan Struktur Materi pelatihan TIK Bagi Guru Sekolah Dasar. Kekurangan dalam pengembangan yang dilakukan adalah belum adanya pemanfaatan media edutainment dalam pengembangan keterampilan TIK. Edutainment berasal dari gabungan antara edu (pendidikan) dan entertainment (hiburan). Edutainment adalah gabungan antara fungsi pendidikan dan konten dalam bentuk hiburan yang bermaksud untuk menciptakan aspek kemenarikan dalam lingkungan belajar (Agustriana, 2013).
Berdasarkan pertanyaan dan tinjauan pustaka, peneliti didorong untuk melakukan penelitian berupa pengembangan modul funteaching dan fun-learning bagi guru dalam rangka meningkatkan kemampuan TIK guru sekolah dasar. Penelitian dan pengembangan ini merupakan salah satu upaya untuk membuat modul elektronik berbasis hiburan dan pembelajaran, yang dapat digunakan guru sebagai pedoman bagi guru dalam membuat media pembelajaran yang sangat menarik dan menyenangkan, sehingga mengembangkan keterampilan TIK guru. Produk e-modul diciptakan melalui kegiatan riset sehingga produk yang dihasilkan dipastikan telah memenuhi persyaratan yang ditentukan. Oleh karena itu, fokus masalah penelitian ini adalah bagaimana pengembangan fun module teacher learning untuk meningkatkan kompetensi ICT guru sekolah dasar yang layak digunakan berdasarkan penilaian dari. ahli materi, ahli media, dan respon oleh guru sekolah dasar. Hasil penelitian tersebut diharapkan mampu membantu guru sekolah dasar dalam memecahkan permasalahan khususnya kurangnya kemampuan ICT di masa pembelajaran daring.

\section{METODE}

Jenis penelitian yang digunakan adalah penelitian dan pengembangan atau research and development (R\&D) yang menghasilkan produk berupa media pembelajaran E-modul bagi guru sekolah dasar. Metode research and development (R\&D) dimaknai sebagai metode penelitian bertujuan untuk memperoleh output berupa produk tertentu dan menguji produk tersebut efektif atau tidak (Sugiyono, 2013). Penelitian dan pengembangan memiliki tujuan guna menghasilkan suatu produk baru melalui kegiatan penelitian yang terintegrasi dalam proses pengembangan produk (Mulyatiningsih, 2012).

Prosedur penelitian ini beradaptasi dari model pengembangan ADDIE yang terdiri dari lima tahapan yang meliputi analisis (analyze), desain (design), pengembangan (development), implementasi (implementation) dan evaluasi (evaluation) (Sugiyono, 2015). Model ini mudah diimplementasikan pada kurikulum yang mengutamakan pada aspek kognitif, afektif, serta psikomotorik (Cheung, 2016). Peneliti menggunakan model ADDIE karena model pengembangan ADDIE ini memiliki 
karakteristik efektif, dinamis dan mendukung kinerja program (Warsita, 2011). Selain itu, model ADDIE sering dipilih karena tahapantahapan merepresentasikan pendekatan yang sistematis guna mengembangkan aspek instruksional (Sugihartini, 2018).

Alat yang dipilih untuk mengumpulkan data kualitas produk: Pertama, kuesioner berupa checklist Google untuk mendapatkan evaluasi dari ahli materi dan ahli media. Kriteria evaluasi produk E-modul Funteach yang digunakan dalam penelitian ini adalah 1) tampilan dan 2) fungsi. Kedua, menggunakan angket berupa checklist untuk mendapatkan data respon dari guru. Aspek-aspek penelitian ini adalah 1) tampilan, 2) kejelasan isi materi,

3) kemudahan penggunaan, dan 4) fungsionalitas.

Teknik analisis data uji kualitas produk bertujuan untuk mengetahui kualitas produk modul elektronik Funteach berdasarkan tanggapan ahli materi, ahli media dan guru. Setelah itu dilakukan analisis teknis data uji terbatas pada guru SD kelas 4 dan 5 SD Muhammadiyah Kota Bantul, yang bertujuan untuk mengetahui keefektifan produk E-modul berdasarkan respon dari guru. Melalui analisis kuantitatif dan deskriptif untuk menganalisis reaksi guru sekolah dasar terhadap modul elektronik funteach.

\section{HASIL DAN PEMBAHASAN}

Berdasarkan desain penelitian dan pengembangan yang telah dilakukan, maka pengembangan E-modul Funteach ini dilaksanakan berupa 5 tahap, yaitu:

\section{Tahap Analisis (Analyze)}

Langkah yang telah dilakukan dalam analisis kebutuhan pengembangan E-modul dan pemahaman terhadap kompetensi ICT dilakukan melalui pengumpulan data kuesioner dan wawancara pada guru. SD Muhammadiyah Bantul Kota dipilih sebagai lokasi penelitian didasarkan pada penelitian Kurniawan dan Hasanah (2021) bahwa guru hanya menggunakan pembelajaran online berupa aplikasi Google Classroom, Jogja Belajar (JB) Class, Zoom Meeting, Google Meeting, dan WhatsApp, karena dinilai mudah digunakan. Setelah peneliti melakukan observasi, ternyata guru belum memiliki pedoman guru yang berbasis edutainment yang secara khusus untuk meningkatkan kompetensi ICT. Disisi lain guru mempunyai tekad dan dorongan yang tinggi guna meningkatkan kompetensi yang mendukung inovasi pembelajaran (Kurniawan dan Hasanah, 2021). Hasil analisis kebutuhan diperoleh diantaranya:

a. Analisis kondisi kegiatan pembelajaran Analisis kondisi kegiatan pembelajaran dilakukan untuk mengidentifikasi peran guru dalam mengelola kelas di masa pandemi. Pendapat guru terhadap kondisi pembelajaran terhadap pembelajaran saat ini $42,85 \%$ responden guru sangat setuju sudah merasa telah menggunakan sistem pembelajaran yang menarik. Begitu pula keoptimalan kegiatan pembelajaran $57,14 \%$ responden sangat setuju. Meskipun demikian 42,8\% guru juga mengakui bahwa siswa terlihat bosan dalam mengikuti pembelajaran. Berdasarkan analisis tersebut tersebut menunjukan bahwa guru sudah berusaha untuk menciptakan kegiatan pembelajaran yang maksimal dan menyenangkan meskipun dalam implementasi terhadap siswa masih belum memenuhi target yang diinginkan. Kebosanan siswa terlihat melalui kurangnya partisipasi dalam mengikuti pembelajaran dari awal hingga akhir.

b. Analisis penggunaan media.

Penggunaan media pembelajaran daring yang dimanfaatkan guru menyesuaikan dengan kondisi guru dan siswa. Media pembelajaran yang sering digunakan yaitu WhatsApp Group. Kendala yang dirasakan oleh $50 \%$ responden mersa kesulitan menggunakan media pembelajaran daring yang bervariasi. Sebanyak $28,57 \%$ guru sulit menggunakan media pembelajaran yang dapat merangsang daya tarik siswa. Hal ini juga selaras dengan riset yang pernah dilaksanakan.

c. Analisis sumber belajar guru sebagai penunjang peningkatan ICT.

Analisis ini bertujuan untuk mendapati sumber belajar yang sudah digunakan guru untuk meningkatkan kemampuan ICT sehingga dapat memberikan kebaruan. Guru menyetujui bahwa penggunaan modul sebagai sumber belajar memberikan kemudahan dan efisien. Kriteria modul yang dijadikan sebagai pertimbangan terlihat dari cakupan materi dan tampilan yang diberikan. Modul cetak lebih banyak digunakan guru, hal ini ditunjukan hanya $42,85 \%$ guru yang sudah memakai emodul. Pemanfaatan e-modul edutainment masih sangat sedikit. Berdasarkan hal tersebut seluruh responden tertarik dengan konsep Emodul berbasis edutainment sebagai sumber belajar penunjang peningkatan ICT. 
d. Analisis ketersediaan sumber belajar elektronik.

Analisis ketersedian sumber belajar elektronik bertujuan untuk melihat peluang produk yang dihasilkan dapat diterima. Guru sudah memiliki perangkat yang memadai dari perangkat komputer, laptop, maupun koneksi internet. Keseluruhan responden tertarik dengan e-modul yang memiliki tampilan lebih modern, fleksibel, dan menarik. Kemenarikan sumber belajar yang ada dapat memudahkan responden memahami materi.

\section{Tahap Desain (Design)}

Tim berdiskusi terkait konsep desain Emodul dan materi pembelajaran di dalamnya. Setelah menemui kesepakatan anggota tim dibagi ke dalam beberapa jobdesk untuk memulai pengerjaan membuat desain dan mengumpulkan bahan materi terkait dengan fun learning dan media evaluasi pembelajaran serta media penyampaian materi.

1. Penyusunan tes Penyusunan tes meliputi penyusunan instrumen asesmen untuk mengukur keberhasilan media dalam meningkatkan kemampuan ICT guru. Assesment yang digunakan yaitu berupa pre test yang diberikan sebelum penggunaan produk dan post test setelah diberlakukanya media, serta assessment yang terdapat didalam modul guna memberikan latihan guru memahami materi secara bertahap.

2. Pemilihan media Pemilihan media yang digunakan dalam membentuk e-modul yaitu didasarkan dengan pertimbangan efisien, efektif, biaya, dan kemudahan mengakses. Berdasarkan kriteria tersebut dipilih website lokal berbasis Html5. E-modul dapat dibuka dengan cara membuka file index.html pada folder hasil ekstrak e-modul. Aplikasi Flip Builder sebagai alternatif lain dalam membuka E-modul. Proses pendistribusian produk menggunakan dua cara yaitu online melalui google drive dan offline melalui flashdisk.

3. Pemilihan format Pemilihan format meliputi materi, media pembelajaran yang dicantumkan, pendekatan, dan pengorganisasian. Peneliti menyusun beberapa bacaan, langkah-langkah, dan video pembelajaran yang dapat dicantumkan di dalam E-modul.

4. Desain awal Pada tahap ini tim peneliti membuat rancangan tampilan dalam bentuk sketsa. Rancangan desain kemudian dikonsultasikan kepada dosen pembimbing dan ditindaklanjuti untuk didesain oleh ahli.

\section{Tahap Pengembangan (Development)} Tahapan pengembangan diawali dengan mengembangkan desain modul yang masih dalam bentuk PDF menjadi sebuah e-modul yang menarik dengan tahapan sebagai berikut: a. Penyelesaian E-modul Tim peneliti menggabungkan materi yang terkumpul berupa asesmen dan soal tes mandiri berupa kuis dan video materi pembelajaran yang dapat diakses secara langsung atau melalui link url youtube Funteach. Desain produk dan materi yang dikumpulkan dalam bentuk PDF diintegrasikan ke dalam pdf, yang telah diubah menjadi situs web lokal berbasis Html5. Modul elektronik dapat dibuka dengan membuka file index.html di folder modul elektronik yang diekstrak. Selanjutnya, tim merevisi modul elektronik yang dikembangkan sebelum dilakukan verifikasi. Berikut ini adalah contoh desain produk E-Module Funteach berupa website lokal yang diakses melalui flip generator. 

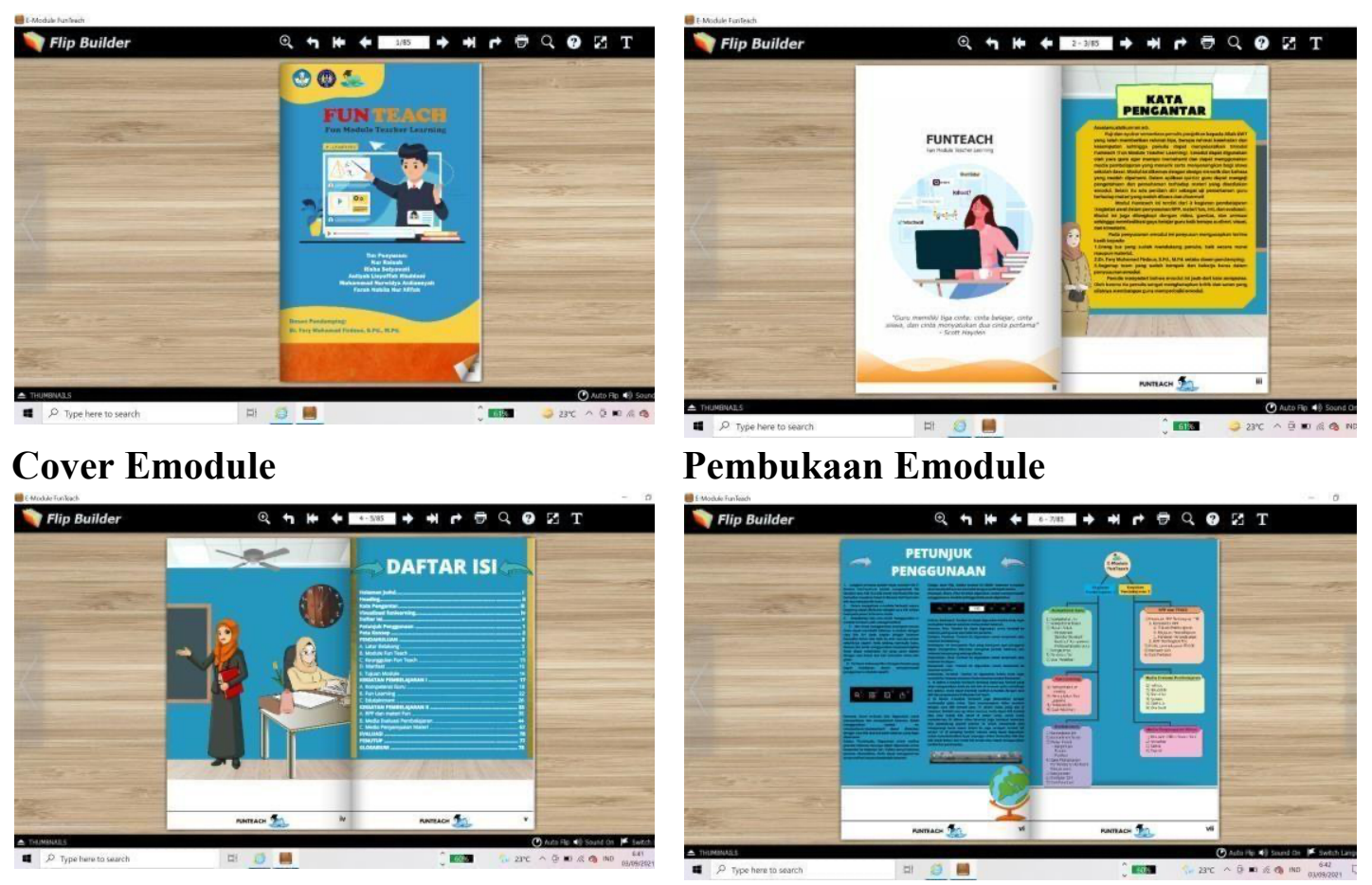

\section{Daftar \\ Isi}

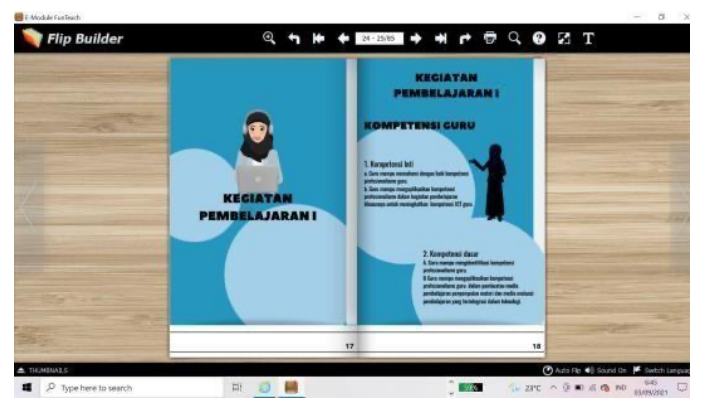

Isi Materi Emodule

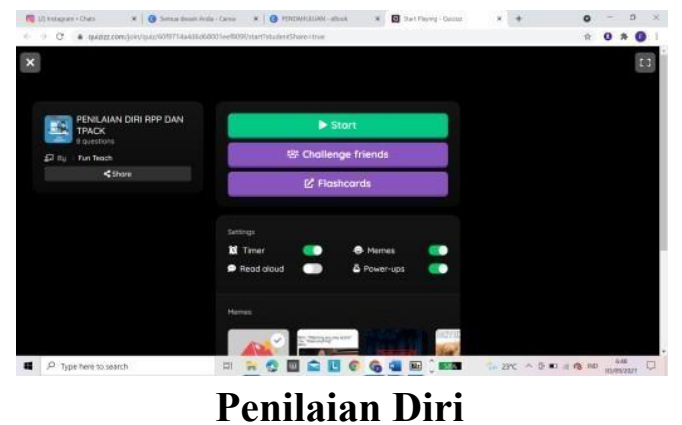

Petunjuk Penggunaan dan

Peta konsep

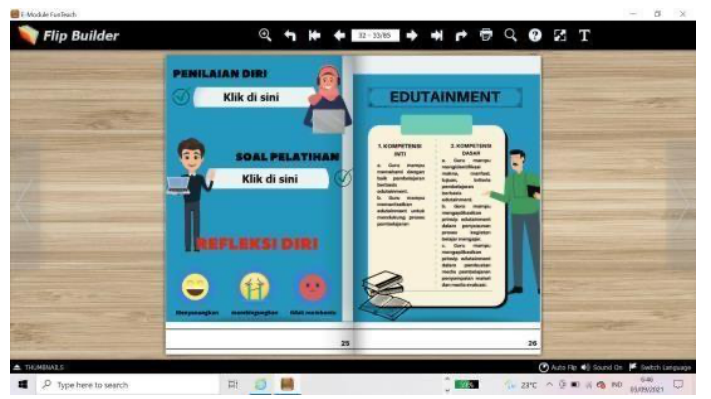

\section{Refleksi Emodule}

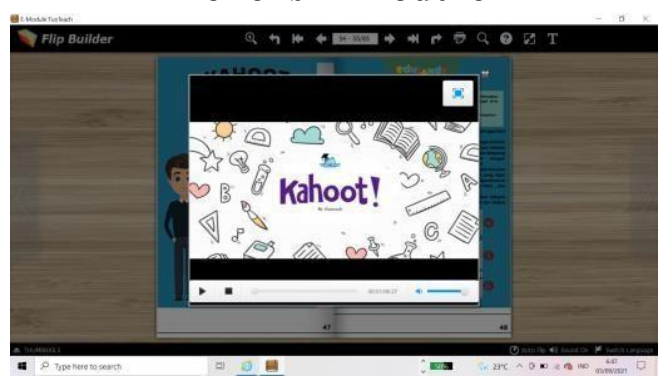

Video Emodule 


\section{b. Validasi Media}

E-modul Funteach kami validasikan kepada ahli materi dan ahli media. Validasi materi dilakukan oleh Bapak Dr. H. Fery Muhamad Firdaus, S.Pd., M.Pd. selaku dosen Pendidikan Dasar Universitas Negeri Yogyakarta. Sedangkan validasi media dilakukan oleh Ibu Evy Nur Rochmah, S.Pd., M.Pd. selaku dosen Media Pembelajaran Pendidikan Dasar Universitas Negeri Yogyakarta. Validasi materi dilakukan pada tanggal 19 Juli 2021. Validasi materi e-modul terdiri dari 3 aspek yaitu pendahuluan, isi, dan penutup. Aspek isi terdiri dari kemenarikan materi dalam memotivasi pengguna, ketepatan dalam penjelasan materi, cakupan materi, kejelasan materi, ketersediaan contoh dan gambar, dan soal latihan yang disertakan. Berdasarkan validasi materi, e-modul Funteach memperoleh skor 3,6 kategori layak dengan beberapa revisi. Revisi harapannya dari validator materi adalah perbaikan bahasa dan tata tulis kalimat.

c. Revisi media

Revisi media dilakukan sesuai dengan saran dari validator ahli materi dan media. Revisi media dilakukan bertujuan untuk memperbaiki produk sesuai dengan ahli sebelum dilakukan validasi yang kedua yaitu serta ujicoba produk. Rincian revisi media yang dilakukan adalah sebagai berikut.

\section{Tabel 4.1 Rincian Revisi Media}

\begin{tabular}{|l|l|l|}
\hline No. & Sebelum Revisi & \multicolumn{1}{|c|}{ Sesudah Revisi } \\
\hline 1. & $\begin{array}{l}\text { Pemberian sub bab } \\
\text { kurang tertata }\end{array}$ & $\begin{array}{l}\text { Sub Bab } \\
\text { disesuaikan } \\
\text { dengan isi materi } \\
\text { dan disusun } \\
\text { secara runtut }\end{array}$ \\
\hline
\end{tabular}

\begin{tabular}{|c|l|l|}
\hline 2. & $\begin{array}{l}\text { Materi media } \\
\text { penyampaian } \\
\text { materi bisa } \\
\text { ditambah }\end{array}$ & $\begin{array}{l}\text { Media penyampaian } \\
\text { Materi ditambahkan } \\
\text { Capcut dan PPT } \\
\text { interaktif. }\end{array}$ \\
\hline 3. & $\begin{array}{l}\text { Tahapan penciptaan } \\
\text { pembelajaran fun } \\
\text { learning kurang } \\
\text { terperinci jelas }\end{array}$ & $\begin{array}{l}\text { Tahapan } \\
\text { menggunakan } \\
\text { urutan angka }\end{array}$ \\
\hline
\end{tabular}

Setelah melakukan revisi media, peneliti kembali melakukan validasi akhir produk. Validasi materi dan media dilakukan pada tanggal 20 Juli 2021. Validasi materi diperoleh skor 4,95 dengan kategori sangat layak. Sedangkan pada validasi media diperoleh media hasil aspek visual dan aspek fitur memperoleh skor 4,75 dengan kategori layak untuk diujicobakan tanpa revisi. Adapun rincian hasil validasi materi dapat dilihat pada tabel berikut.

Tabel 4.2 Validasi Materi

\begin{tabular}{|l|c|c|c|c|}
\hline \multirow{2}{*}{ Validator } & \multicolumn{2}{|c|}{ Aspek } & Rata-Rata \\
\cline { 2 - 5 } & $\begin{array}{l}\text { Aspek } \\
\text { Penda } \\
\text { huluan }\end{array}$ & Aspek Isi & $\begin{array}{l}\text { Aspek } \\
\text { Penutup }\end{array}$ & \\
\hline Ahli Materi & $\mathbf{5 , 0}$ & $\mathbf{4 , 8 5}$ & $\mathbf{5 , 0}$ & $\begin{array}{l}\mathbf{4 , 9} \\
\mathbf{5}\end{array}$ \\
\hline Kategori & & & $\begin{array}{l}\text { Sangat } \\
\text { Layak }\end{array}$ \\
\hline
\end{tabular}

Sedangkan hasil validasi media sebagai berikut. Tabel 4.3 Validasi Media

\begin{tabular}{|c|c|c|c|}
\hline \multirow{2}{*}{ Validator } & \multicolumn{2}{|c|}{ Aspek } & \multirow{2}{*}{$\begin{array}{c}\text { Rata- } \\
\text { Rata }\end{array}$} \\
\cline { 2 - 4 } & $\begin{array}{c}\text { Aspek } \\
\text { Tampilan }\end{array}$ & Aspek Fitur & \\
\hline Ahli Media & 4,73 & 4,77 & 4,75 \\
\hline Kategori & & Sangat Layak \\
\hline
\end{tabular}

Setelah tervalidasi $e$-modul dan telah kami perbaiki, selanjutnya produk siap untuk diimplementasikan.

\section{Tahap Impelementasi (Implementation)}

Tahap implementasi produk e-modul dilakukan pada guru kelas 4 dan 5 SD Muhammadiyah Bantuk Kota pada hari Selasa, 3 Agustus 2021 dengan melakukan pengenalan produk terlebih dahulu. Pengerjaan soal pretest 
melalui google form dilaksanakan pada 4 Agustus 2021. Ujicoba produk secara mandiri dilaksanakan mulai tanggal 5 Agustus selama 7 hari sampai dengan 12 Agustus 2021 dengan pemantauan oleh tim melalui koordinasi melalui grup WhatsApp. Pada hari Jumat, 13 Agustus bapak/ibu guru mengerjakan soal posttest.

\section{Tahap Evaluasi (Evaluation)}

Kegiatan penilaian berupa analisis emodul dalam termin implementasi yaitu menggunakan menganalisis output pretest \& postest yg sudah dikerjakan sang Bapak/mak pengajar. Sehingga bisa mengetahui keefektifan produk pada menaikkan kompetensi ICT pengajar sekolah dasar. Selain itu, tim jua melakukan penilaian menggunakan melakukan observasi pada pengajar terhadap pengalaman penggunaan e-modul menjadi panduan pembelajaran buat membangun fun learning \& pembuatan media pembelajaran yg menarik dan menunjang ketercapaian belajar siswa. Kegiatan respon pengajar terhadap penggunaan e-modul dilaksanakan secara daring memakai google form.

\section{PENUTUP}

Setelah melakukan pengkajian teori dan hasil penelitian maupun pembahasan, maka dapat ditarik suatu kesimpulan sebagai berikut: 1) telah dihasilkan produk E- modul Funteach sebagai pedoman bagi guru untuk meningkatkan kompetensi ICT. Meliputi karakteristik proses (analisis, desain produk, pengembangan, implementasi, dan evaluasi) dan karakteristik produk (judul, petunjuk penggunaan, pendahuluan, materi fun learning, materi edutainment, fun media pembelajaran penyampaian materi, dan fun media evaluasi).

2) E-modul Funteach memperoleh penilaian dari reviewer ahli materi mendapat skor ratarata 4,95 yang berarti sangat layak dan penilaian ahli media mendapat skor rata-rata 4,75 yang berarti sangat layak, 3) respon dan tanggapan guru kelas 4 dan 5 SD terhadap emodul Funteach memperoleh skor rata-rata yang berarti 4,5 yang berarti sangat layak untuk diimplementasikan lebih lanjut. Dengan demikian sesuai batas-batas hasil review dan tanggapan guru, produk e-modul Funteach dalam penelitian ini dapat digunakan oleh guru sekolah dasar.

\section{UCAPAN TERIMA KASIH}

Puji syukur kehadirat Allah SWT yang telah memberikan kelancaran dalam pelaksanaan penelitian mahasiswa dan pembuatan artikel ilmiah.

Adapun sebagian besar isi artikel ilmiah ini meliputi, pendahuluan, tinjauan pustaka, metode penelitian, hasil dan pembahasan, kesimpulan dan penutup.

Ucapkan terima kasih dan penghargaan setinggi-tingginya penulis sampaikan kepada:

1. Bapak Dr. H. Fery Muhamad Firdaus, S.Pd., M.Pd. selaku dosen pendamping tim yang telah menyediakan waktu, tenaga, dan pikiran untuk mengarahkan kami dalam penelitian ini.

2. Validator ahli materi, ahli media, dan guru.

3. Bapak Andika, S.Pd. selaku kepala SD Muhammadiyah Bantul Kota

4. Bapak/ Ibu guru selaku guru kelas 4 dan 5 SD Muhammadiyah Bantul Kota

5. Pihak-pihak yang membantu dalam penelitian.

Penulis menyadari bahwa dalam penulisan artikel ilmiah ini masih terdapat banyak kekurangan. Oleh karena itu, penulis mengharapkan kritik dan saran yang bersifat membangun dalam rangka penyempurnaan penelitian selanjutnya.

\section{DAFTAR PUSTAKA}

Agustriana, N. 2013. Pengaruh Metode Edutainment dan Konsep Diri Terhadap Keterampilan Sosial Anak. Jurnal Pendidikan Usia Dini. 7(2).

Alifia, Ulfah., Bima, Luhur., Barasa, Arjuni 
Rahmi., Bima, Luhur., dkk. 2020 Belajar Dari Rumah: Potret Ketimpangan Pembelajaran pada Masa Pandemi COVID-19. Catatan Penelitian SMERU Reseach Institute. Diakses 20 Juli 2021.

Badan Pusat Statistik. 2019. Potret Pendidikan Indonesia: Statistik Pendidikan 2019.

Jakarta: Badan Pusat Statistik.

Batubara, H. H. (2015). Pengembangan media pembelajaran interaktif pada materi operasi bilangan bulat. Muallimuna. Jurnal Madrasah Ibtidaiyah, 1(1), 1-12.

Cheung. Lawrence. 2016. Using the ADDIE Model of Intructional Design To Teach Chest Radiograph Interpretation. Diakses dari laman https://www.hindawi.com/journals /jbe/2016/9502572/abs/ pada 18 Agustus 2021. Kemendikbud. 2020. Survei Guru Pembelajaran Jarak Jauh Pada Masa Pandemi COVID-19.

Kuncahyono. 2019. Pengembangan softskill teknologi pembelajaran melalui pembuatan emodul bagi guru sekolah dasar. Jurnal Pendidikan dan Pembelajaran Dasar. 6 (2): $128-139$.

Mulyatiningsih, E. 2012. Metode Penelitian Terapan Bidang Pendidikan. Alfabeta. Bandung.

Nadiem, A. M. 2020. Pemaparan program guru dalam peluncuran merdeka belajar episode 5 tentang "Guru Penggerak." https://youtu.be/X6vP4AkEsLM.

Niarsa, A. 2013. Studi Kompetensi Guru Dalam Memanfaatkan Media Pembelajaran Berbasis Teknologi Informasi Dan Komunikasi (TIK) DI SD Negeri 01 Ledok Kecamatan Sambong Kabupaten Blora. Universitas Negeri Semarang.

Prawiradilaga, Dewi Salma dkk. 2013. Mozaik Teknologi Pendidikan E-Learning.

Kencana. Jakarta.

Ramly, A. 2020. Kesehatan Jiwa Siswa Saat Pandemi COVID-19 dan Pembelajaran Jarak Jauh. UNICEF. Indonesia.
Rivalina. 2014. Kompetensi Teknologi Informasi dan Komunikasi Guru dalam Peningkatan Kualitas Pembelajaran. Jurnal Teknodik. 18 (2).

Satriawan, W. Santika, I. D. Dan Naim, A. 2021. Guru Penggerak Dan Transformasi Sekolah Dalam Kerangka Inkuiri Apresiatif. AlIdarah: Jurnal Kependidikan Islam, 11(1): 112.

Save The Children. 2020. Indonesia COVID-19 Rapid Needs Assesment Report April 2020. Save The Children. Jakarta.

Sugihartini, N. Yudiana, K. 2018. ADDIE Sebagai Model Pengembangan Media Instruksional Edukatif (MIE) Mata Kuliah Kurikulum dan Pengajaran. Jurnal Pendidikan Teknologi dan Kejuruan. 15 (2): 277.

Sugiyono. 2013. Metode Penelitian Kuantitatif, Kualitatif, dan $R \& D$. Alfabeta.

Bandung.

Sugiyono. 2015. Metode Penelitian Kuantitatif, Kualitatif, dan R\&D. Alfabeta.

Bandung.

Sugiyono. 2017. Metode Penelitian Kuantitatif, Kualitatif, dan R\&D. Alfabeta. Bandung.

Sukardjo. 2008. Kumpulan Materi Evaluasi Pembelajaran. Yogyakarta. Universitas Negeri Yogyakarta.

UNESCO. 2011. UNESCO ICT Competency Framework for Teachers. The United Nations Educational : Scientific and Cultural Organization.

UNESCO. 2020. Global Education Coalition, COVID-19 Education Response. Uno, $\mathrm{H}$. 2016. Teori Motivasi dan Pengukurannya. PT. Bumi Aksara. Jakarta. Warsita, B. 2011. Pendidikan Jarak Jauh. PT. Remaja Rosdakarya. Bandung. 